\title{
New data about the oldest european lagomorpha: Description of the new genus Ephemerolagus nievae gen. nov. et sp. nov.
}

\author{
Monique VIANEY-LIAUD* \& Renaud LEBRUN
}

Laboratoire de Paléontologie, Institut des Sciences de l'Evolution, Université Montpellier II cc 064, place Eugène Bataillon, 34095 Montpellier, France; monique.vianey-liaud@univ-montp2.fr

* Corresponding author

Vianed-Liaud, M. \& Lebrun, R. 2013. New data about the oldest European lagomorpha: Description of the new genus Ephemerolagus nievae gen. nov. et sp. nov. [Nuevos datos acerca del más antiguo lagomorfo europeo: descripción del nuevo género Ephemerolagus y nueva especie]. Spanish Journal of Palaeontology, 28 (1), 3-16.

Manuscript received 27 April 2012

Manuscript accepted 21 September 2012

(C) Sociedad Española de Paleontología ISSN 2255-0550

\section{ABSTRACT}

Early Oligocene lagomorphs from south-western France were previously known only from one isolated molar (Desmatolagus sp.) from Ravet (Quercy), an early Oligocene fissure-filling (MP21 level, $33 \mathrm{Ma}$ ). New material, a left lower jaw bearing $\mathrm{P} / 3$ to $\mathrm{M} / 1$, allows for the description of a new genus and a new species: Ephemerolagus nievae, on the bases of morphological analysis and micro-computed tomography $(\mu \mathrm{CT})$ scan sections. It has been compared to the German contemporaneous specimens ("Shamolagus" franconicus from Möhren 19 and Möhren 20, MP21), and to the Asian and North American Palaeogene genera. This species displays peculiar derived characters, like the very short incisor (ending below P/3), not found in Asian or North American early lagomorphs, or in late Palaeogene European genera, or the lack of $\mathrm{M} / 3$ and the highly molarized $\mathrm{P} / 4$.

Keywords: Lagomorphs, Paleogene, Oligocene, Europe, tooth morphology.

\section{RESUMEN}

Los lagomorfos del Oligoceno temprano del suroeste de Francia eran previamente conocidos por un único molar aislado (Desmatolagus sp.) de Ravet (Quercy), un relleno del nivel MP 21 (33 Ma). Nuevo material, una mandíbula inferior cortando del $\mathrm{P} / 3$ al M/1, permite la descripción de un nuevo género y nuevo especie: Ephemerolagus nievae, sobre la base de un análisis morfológico y secciones de $\mu \mathrm{CT}$ Scan. Se la ha comparado con los especímenes alemanes contemporáneos ("Shamolagus" franconicus de Möhren 19 y Möhren 20, MP21), y con los géneros del Paleógeno asiático y norteamericano. Esta especie muestra caracteres derivados peculiares, como un incisivo muy corto (terminando debajo del $\mathrm{P} / 3$ ), que no aparece en los lagomorfos tempranos de Asia o Norteamérica, o los géneros del Paleógeno tardío de Europa, la falta del M/3 y la presencia de un $\mathrm{P} / 4$ altamente molarizado.

Palabras clave: Lagomorfos, Paleógeno, Oligoceno, Europa, morfología dental. 


\section{INTRODUCTION}

The first adaptive radiation giving rise to lagomorphs took place in Asia probably as early as the early Eocene (e.g., Rose et al., 2008). Later, during the middle and late Eocene and the early Oligocene, Lagomorpha were diversified in North America and Asia, as shown from their rich record in Palaeogene deposits of these areas. About 50 species and 25 genera have been described (e.g., Matthew \& Granger, 1923; Wood, 1940; Burke, 1941; Bohlin, 1942; Dawson, 1958, 1967; Li, 1965; Sych, 1975; Huang, 1987; Erbajeva \& Däxner-Höeck, 2001; Meng \& Hu, 2004; Averianov \& Lopatin, 2005; Meng et al., 2005; Lopatin \& Averianov, 2006; Erbajeva, 2007; Wang, 2007; Erbajeva et al., 2011).

In Europe, Palaeogene lagomorphs were long known but only from two genera (Piezodus and Amphilagus), found in late Oligocene deposits from France and Germany (e.g., von Meyer, 1843; Pomel, 1853; Viret, 1929; Tobien, 1963, 1974; Mörs \& Kalthoff, 2010). Almost simultaneously, López-Martínez \& Thaler (1975) and Heissig \& Schmidt-Kittler $(1975,1976)$ gave evidence for early Oligocene lagomorph immigration, going with the "Grande Coupure" event (Stehlin, 1909). If the former referred the unique tooth from Ravet (Quercy, France) to the Asian genus Desmatolagus, the latter described a new species from Möhren 19 (Bavaria, Germany) of a European genus Titanomys franconicus (Heissig \& SchmidtKittler, 1975). Then, this species has been removed from Titanomys, and referred to the Asian genus Shamolagus when getting additional material from the type locality, and from another early Oligocene locality, Möhren 20 (Heissig $\&$ Schmidt-Kittler, 1976). Tobien (1986) has used this generic attribution for the species $S$. franconicus.

Until now, the whole early Oligocene described material comprised isolated teeth only. Here, a fairly preserved right dentary bearing $\mathrm{I} / 2$ to $\mathrm{M} / 2$, from Ravet locality (Quercy, south of France), allows us to reconsider the systematic status of these fossils, and to describe a new genus. New critical observations can be made with the support of a micro-computed tomography $(\mu \mathrm{CT})$ scan analysis. This technique makes possible to access inner structures of fossil organisms in a non-destructive manner.

\section{MATERIAL AND METHOD}

$\mathrm{X}$-ray $\mu \mathrm{CT}$ was used to acquire $3 \mathrm{D}$ data. The mandible was scanned using a Skyscan $1076 \mu \mathrm{CT}$ equipment, which is part of the Montpellier RIO Imaging (MRI) platform, at a resolution of $36 \mu \mathrm{m}$. 3D surfaces representing the mandibular bone, the teeth and root cavities were produced with Avizo 7.0.1 (Visualization Sciences Group) via thresholding and manual segmentation.
Measurements of teeth have been taken with a "Measuroscope Nikon" (Table 1).

Table 1. Measurements of the Lagomorpha gen. nov. spec. nov., RAV546, from Ravet (Quercy MP21).

\begin{tabular}{lcccc}
\hline $\begin{array}{l}\text { Tooth category } \\
\text { Measurements (mm) }\end{array}$ & $\mathrm{P} / 3$ & $\mathrm{P} / 4$ & $\mathrm{M} / 1$ & $\mathrm{M} / 1$ (RAV26) \\
\hline Occlusal length & 1.66 & 2.86 & 2.70 & - \\
Alveolar length & 2.24 & 2.93 & 3.37 & $3.25+$ \\
Trigonid width & 1.39 & 2.19 & 2.49 & broken \\
Talonid width & 1.61 & 2.29 & 2.06 & 2.17 \\
Metaconid height* & 3.76 & 4.71 & 4.43 & 4.40 \\
Protoconid height & 3.86 & 5.42 & 4.57 & $?$ \\
Mesoflexid height** & $0.35 ?$ & 2.05 & 1.36 & 1.70 \\
$\begin{array}{l}\text { Hypoflexid height** } \\
\text { Length of inferior molar series } \\
\text { (at alveoli, including that of } \mathrm{M} / 2 \text { ): } 12 \mathrm{~mm}\end{array}$ & 3.26 & 2.71 & 2.78 \\
\hline
\end{tabular}

*: measured from the metaconid top to the divergence point of the two roots.

**: measured from the occlusal plane of these flexids to their basal end.

Photographs of the original material of "Shamolagus" franconicus have kindly been made available from the Bayerische Staatssammlung für Paläontologie und Geologie, München.

\subsection{Terminology}

We use the dental terminologies of lagomorphs provided by López-Martínez (1974), and Kraatz et al. (2010). Kraatz et al. (2010) have proposed applying the general mammalian dental nomenclature to the lagomorphs, on the basis of comparisons of the dental patterns of the earliest lagomorphs and of their sister group, the mimotonids (e.g., Averianov, 1998; Meng \& Hu, 2004). Since the 90s of the twentieth century, the main discussion has concerned the homology of the central cone of upper molars. For Kraatz et al. (2010), it is a metaconule, which is consistent with its connection with the metacone, as seen in mimotonids. As our new material is a lower jaw, we will not go further in the discussion of the upper cheek teeth homologies.

There were fewer problems of homologies for the lower teeth, where the mammalian components of the trigonid and talonid are more easily recognizable (Figs 1a-1b). However, some comments must be made 

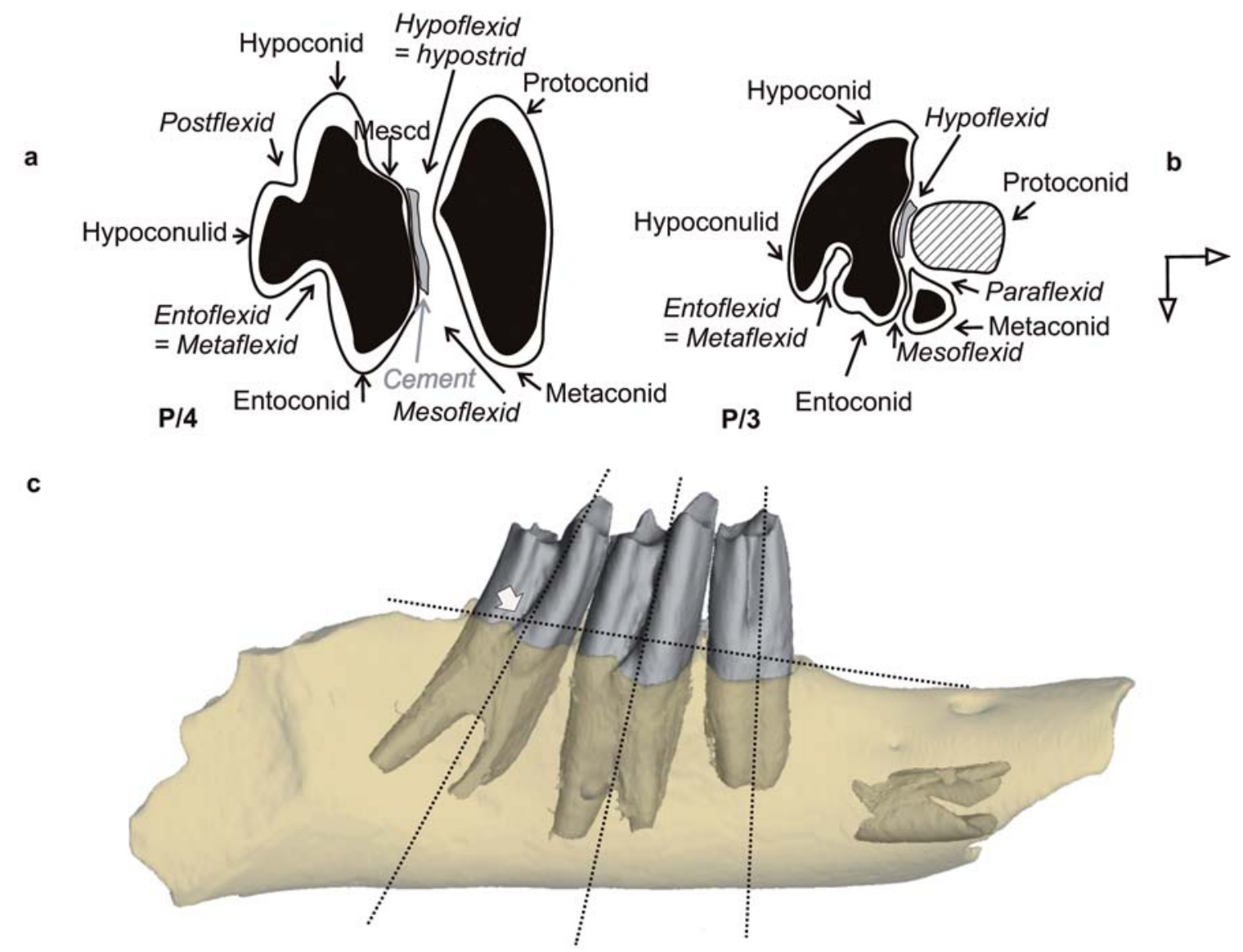

Figure 1. Terminology used (modified, from Angelone, 2007 and Kraatz et al., 2010). a) Lower P/4 and molars of primitive Lagomorpha. b) Lower P/3. c) Virtual reconstruction of the specimen RAV546 showing teeth roots. The dotted lines indicate the directions of slope of the teeth of that specimen, and the trace of the alveolar surface, horizontal. The angle of the slope $(\alpha)$ of each tooth (given in the text) is measured between the horizontal line and that drawn down through the hypoflexid to the divergence point of the two roots. Arrows indicate mesial and lingual directions.

about the ambiguous terminology for Late Oligocene European lagomorphs found in Mörs \& Kalthoof (2010; p. 87). We do not agree with their use of three terms: hypoflexid, mesoflexid and paraflexid. For Tobien (1974) and followers, the reentrant (or sinusid) between the protoconid and the hypoconid is named "protoflexid". But, more generally in mammal dental terminology and for lagomorphs (López-Martínez, 1974; Angelone, 2007; Kraatz et al., 2010), this sinusid is named hypoflexid, whereas for Tobien the hypoflexid is generally the small postero-sinusid (postflexid) labial to the junction between the posterior arm of the hypoconid and the hypoconulid. For the same reason, we do not agree with their position of the "mesoflexid", the small lingual synclinid between the entoconid and the hypoconulid. It is clearer to name it "metaflexid" (López-Martínez, 1974) or "entoflexid", as it separates the entoconid from the postcingulum.
"Mesoflexid" would be restricted to the lingual valley separating the trigonid from the talonid. Thus, the reentrant named by Tobien and followers "paraflexid" is the mesoflexid. The paraflexid (e.g., Angelone, 2007; Fig. 2 ) is the antero-labial reentrant located in front of the metaconid. Mörs \& Kalthoff (2010; p. 85) have indicated that they mainly followed the terminology of Angelone (2007), but in their comparison between the terminology they used and that of Tobien (1974), for example the Hinter Aussenbucht (Pes) of Tobien is their hypoflexid (Mörs \& Kalthoff, 2010; table 3), in the same way as in Tobien, and not as in Angelone. This is confusing, because, they have actually followed Tobien's terminology, and not that of Angelone. 


\section{SYSTEMATIC PALEONTOLOGY}

\author{
Order LAGOMORPHA Brandt, 1855 \\ Family Indeterminate
}

The extant Lagomorpha are divided into two families: the Leporidae Thomas, 1897, and the Ochotonidae Thomas, 1897. Eocene and Oligocene lagomorphs have been arranged either between these two families (e.g., Dawson, 1967; Tobien, 1974; López-Martínez, 2008), even if they do not share diagnostic characters with them, or their familial position is not addressed (e.g., Meng $\& \mathrm{Hu}, 2004$; Meng et al., 2005). Another alternative is retained by some authors, which have either defined or used subfamilies (Burke, 1941; Dawson, 1958), or even families (e.g., Gureev, 1964; Averianov \& Lopatin, 2005; Erbajeva, 2007; Erbajeva et al., 2011). The latter practice remains highly controversial, the definition of (sub)families being subjective and questionable, given the frequent poor quality of the fossil record and the high variability of fossils (often related to ontogeny), thus it "enhances the instability of the nomenclature because new information will influence the reconstruction of lineages and thereby the content of the (sub)families" (Bendukidze et al., 2009; p. 347). On the basis of the incisor enamel microstructure of a few genera, Martin (2004) has argued for an early divergence between Leporidae (single layered enamel) and Ochotonidae (double-layered enamel). The study of the enamel microstructure of the Ravet incisor has not been possible due to its state of preservation; moreover, no information is available on the maxillary teeth: thus the familial attribution of this new taxon remains uncertain.

Genus Ephemerolagus gen. nov.

Type species. Ephemerolagus nievae gen. nov. spec. nov.

Derivatio nominis. First lagomorph immigrant in Europe, during the "Grande Coupure" event, at the beginning of the Oligocene, but stratigraphical record limited to the first Oligocene level (Early Rupelian, MP21; Biochro'M, 1997).

Diagnosis of the genus. That of the type (and presently unique) species.

The new genus (and species) described below shows primitive features, as rooted cheek teeth, which present a relatively complicate dental pattern (e.g., Tobien, 1978; p. 161; López-Martinez, 2008); but they also display apomorphic ones, like the short lower incisor, the lack of $\mathrm{M} / 3$, or the highly molarized $\mathrm{P} / 4$.

Ephemerolagus nievae gen. nov. spec. nov. (Figs 2-5).

1975 Desmatolagus sp. López-Martínez \& Thaler.
Derivatio nominis. Species named in honor of our late colleague Nieves López-Martínez.

Holotype. Right dentary, with alveolus and a fragment of $\mathrm{I} / 2$, and $\mathrm{P} / 3-\mathrm{P} / 4-\mathrm{M} / 1$, RAV546.

Paratype. RAV26, M/1 (López-Martínez \& Thaler 1975; 245, Fig. 1).

Diagnosis. Primitive lagomorph of great size (comparable in size with Desmatolagus robustus and D. ardynense, and greater than Amphilagus antiquus). Dentary with the ventral surface of the body horizontal, from the level of the anterior foramen mentale to the beginning of the angular process.

Lower teeth formula. I: $/ 1, \mathrm{P}: / 2, \mathrm{M}$ : $/ 2$; cheek teeth incompletely hypsodont, with strong roots; length mandibular cheek teeth alveoli: $15,33 \mathrm{~mm}$.

Incisor, trapezoidal in transversal section, short, ending below the anterior root of $\mathrm{P} / 3$.

$\mathrm{P} / 3$ with talonid well developed, posterolophid distinct to the entolophid, and separated by a shallow metaflexid on the weakly worn specimen. $\mathrm{P} / 4$ is larger than $\mathrm{M} / 1$, with its trigonid a little wider than talonid, and with marked hypoconulid, featured lingually by the metaflexid, and labially by a short postflexid. Talonid of $\mathrm{M} / 1$ as in $\mathrm{P} / 4$, but a little shortened lingually and antero-posteriorly. M/3 absent.

Slopes of cheek teeth increasing from nearly vertical $\mathrm{P} / 3$ (inter-root axis $\alpha=85^{\circ}$ ) to strongly inclined $\mathrm{M} / 2$ ( $\alpha$ more than $\left.130^{\circ}\right)$. Thin cement layer inside the hypoflexid.

Differential diagnosis. Ephemerolagus differs from: 1) Early Oligocene North American genera Chadrolagus, Palaeolagus and Megalagus in its less high cheek teeth crowns, the incisor shorter, the different shape of $\mathrm{P} / 3$ and the absence of $\mathrm{M} / 3,2)$ Desmatolagus, Shamolagus, Strenulagus and Sinolagomys in the rectilinear shape of the lower surface of the dentary horizontal ramus, and on the location of the foramen mentale anterior and posterior, 3) Desmatolagus, and Sinolagomys in its $\mathrm{P} / 4-\mathrm{M} / 1$ talonid wider relatively to the trigonid, 4) Aktashmys in the absence of the paracristid on $\mathrm{P} / 4$, and the talonid less wide than the trigonid on $\mathrm{M} / 1$, and its diverging roots on $\mathrm{P} / 4-\mathrm{M} / 1$, 5) Desmatolagus, Gobiolagus, Shamolagus, Strenulagus, Aktashmys, and Amphilagus in the absence of M/3, 6) late Oligocene Amphilagus and Piezodus, and early Miocene Titanomys, in its weaker hypsodonty and thus a less depth mandibular ramus, and in its larger size, 7) Amphilagus and Titanomys in its more anterior foramen mentale, its double-rooted and less reduced $\mathrm{P} / 3$ and in the absence of a low anterocingulid on $\mathrm{P} / 3$, and 8) Piezodus in the absence of anterocingulid/anteroconid on $\mathrm{P} / 3$, and in the presence of only one shearing blade on last premolars and $\mathrm{M} / 1-\mathrm{M} / 2$, the primary shearing blade (PSB, von Koenigswald et al., 2010). 
a
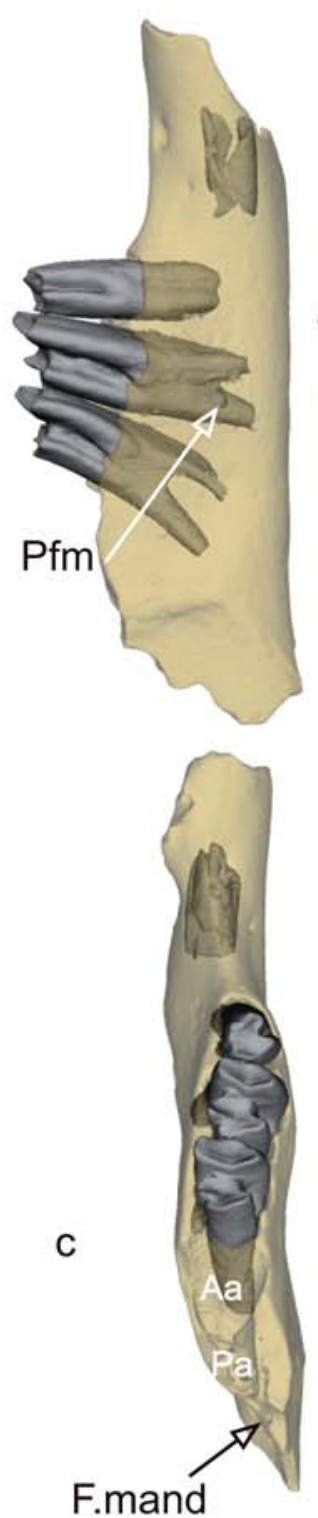

b
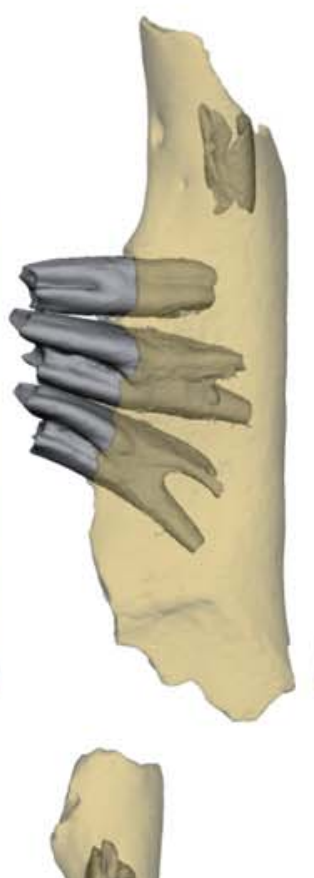

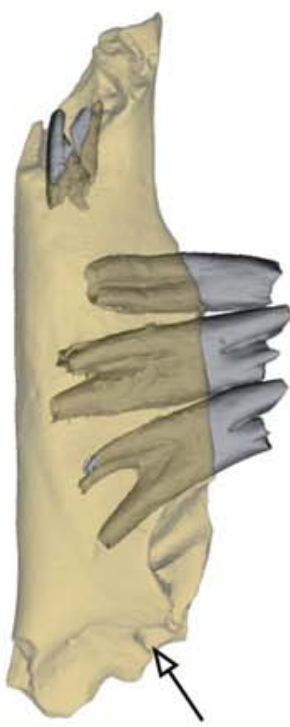

F.mand

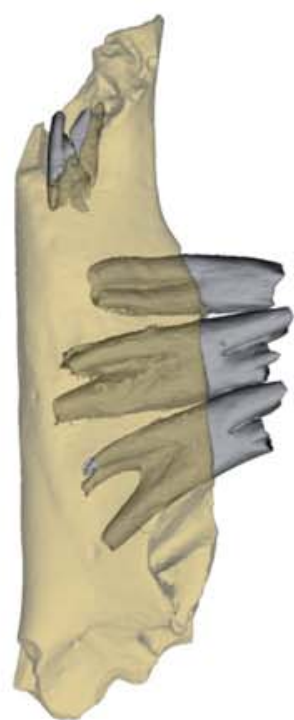

$1 \mathrm{~cm}$

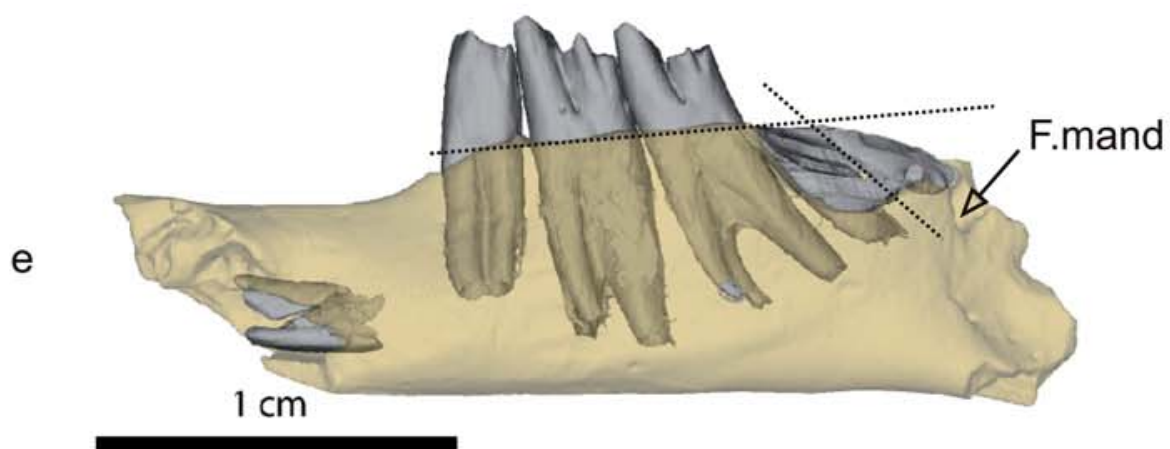

Figure 2. Stereo 3D views of the virtual reconstructions of Ephemerolagus nievae gen. nov. spec. nov. RAV546, from Ravet (Quercy MP21), body of the mandible, bearing P/3, P/4, M/1. a) Lingual view. b) Medial view. c) Occlusal view. d) Front view. e) Same, in lingual view, with reconstruction of $\mathrm{M} / 2$ roots. F.mand $=$ Foramen mandibulare; $\mathrm{Pfm}=$ posterior foramen mentale; $\mathrm{Aa}=$ anterior alveolus of $\mathrm{M} / 2 ; \mathrm{Pa}=$ posterior alveolus of $\mathrm{M} / 2$. 
Description. The specimen, a right dentary, is preserved from the posterior end of the symphysis to the anterior part of the masseteric fossa (total length between the higher point of the symphysis to the posterior alveolar limit of $\mathrm{M} / 2=21.8 \mathrm{~mm}$; total alveolar length, from $\mathrm{P} / 3$ to $\mathrm{M} / 2$ alveoli $=15.33 \mathrm{~mm}$; dentary height below $\mathrm{M} / 1$ talonid $=6.79 \mathrm{~mm}$ ). The symphysis is slightly curved only before $\mathrm{P} / 3$.

The body of the mandible is slender, and its ventral surface quite horizontal from the level of the anterior foramen mentale to the beginning of the ramus. The anteriormost foramen mentale is nearly at mid length of the diastema, but situated slightly closer to the anterior border of the $\mathrm{P} / 3$ alveolus $(=4.09 \mathrm{~mm})$ than to the higher point of the symphysis $(=4.37 \mathrm{~mm})$. A tiny foramen is situated posteriorly and close to the former, but slightly below. The posterior foramen mentale, as well developed as the anterior one, is placed below the middle of $\mathrm{P} / 4$, at mid-height of the dentary. On the labial side of the mandible, the masseteric fossa ends below the anterior alveolus of $M / 2$. On the lingual side of the mandible, the pterygoid fossa ends below the wide mandibular foramen. A tiny foramen is located in this fossa (Fig. 3i). Even if the ramus is broken behind the $\mathrm{M} / 2$ alveoli, it is possible to determine the position of the mandibular foramen, inferior to the occlusal surface of the tooth row (Char. 57 in Wible, 2007). The upper masseteric line begins at the level of the alveolus of the posterior root of $\mathrm{M} / 2$, and runs up nearly vertically. A faint bulge marks its anterior end, and the beginning only of its lower part is visible. It is not possible to know if it is present along the ventral margin of the jaw body; either it is restricted posteriorly on the ramus, or it is completely absent. It is not possible to decide, since the ramus is nearly completely missing.

As seen on the scan pictures (Fig. 4), the alveolus of the incisor ends below the anterior root of $\mathrm{P} / 3$. The incisor appears trapezoidal in front section, like in Amphilagus antiquus (Tobien, 1974; fig. 19). The scan images show that the premolars and molars are not fully hypsodont, as the roots are clearly individualized and long. The enamel is higher on the distal side of the crown than on its mesial side (semi-hypsodont, or asymmetrical, or unilateral, hypsodonty). If $\mathrm{P} / 3$ has two attached roots, $\mathrm{P} / 4$ and $\mathrm{M} / 1$ display two anterior roots, fused at their upper part, but clearly separated at their bases, and labio-lingually aligned. Their posterior root is the strongest, occupying the whole width of the teeth. $\mathrm{P} / 3$ roots are vertically inserted; those of $\mathrm{P} / 4$ are gently inclined, whereas those of $\mathrm{M} / 1$ are strongly and posteriorly inclined. $\mathrm{M} / 2$ is not preserved on RAV546, but the shape of the alveoli shows that the anterior ones (if two) are as sloped as the posterior root of $\mathrm{M} / 1$, and the posterior alveolus is much more inclined and quite less deep than the anterior. The shape of these alveoli does not fit with the roots of RAV26, which are less steep. This tooth is a M/1 rather than a $\mathrm{M} / 2$, contra López-Martínez
$\&$ Thaler (1975). The teeth are not much worn, so that the shallow valleys and grooves are well distinguished on $\mathrm{P} / 3$ and on the talonids of $\mathrm{P} / 4-\mathrm{M} / 1$.

$\mathrm{P} / 3$ is short compared to $\mathrm{P} / 4$ and nearly vertical $(\alpha$ $=85^{\circ}$ ). The talonid appears wider and longer than the trigonid. The hypoflexid (sinusid) is deeply marked, even if less than on $\mathrm{P} / 4$. The trigonid is only slightly higher than the talonid. The metaconid is attached to the entoconid, the mesoflexid being narrow and limited to the very upper part of the crown. The metaconid is isolated from the anteroconid + protoconid by a shallow paraflexid. Because the trigonid is damaged labially, it is not possible to distinguish the complete outline of the protoconid. The talonid includes a well-marked hypoconulid, connected to the hypoconid. The entoconid displays a weak bilobation (visible only in a sharp incision of the enamel surface). The shallow metaflexid is one-third of the talonid width. All the shallow valleys of the occlusal surface would disappear with wear, except the hypoflexid, as seen on CT sections (Fig. 3). It is difficult to distinguish cement filling even in the hypoflexid.

The $\mathrm{P} / 4$ is weakly posteriorly inclined $\left(\alpha=95^{\circ}\right)$. As for $\mathrm{P} / 3$, the talonid is longer and wider than the trigonid. Cement is clearly present in the hypoflexid. The higher talonid is well separated from the trigonid; one can see an angle (edge) at the junction of the posterior arms on the two only identifiable cuspids, which are the hypoconid and metaconid. The enamel is only slightly thinner on the mesial flank of the trigonid and talonid than on the distal one; the latter displays the unique vertical wear facet on $\mathrm{P} / 4$ (and $\mathrm{M} / 1$ ). It is the same for the trigonid, but there is no vertical wear facet. Mesoflexid and hypoflexid communicate, and display a thin cement filling. A wide undulation underlines the connection between the anterior arm of the entoconid and hypoconid. It could be a vestigial mesoconid. The hypoconulid draws a posterior lobe, which is connected to the hypoconid. This connection is marked by a kind of postflexid. The hypoconulid is separated from the entoconid by a shallow entoflexid (= metaflexid).

The $\mathrm{M} / 1$ is more posteriorly inclined than $\mathrm{P} / 4(\alpha=$ $\left.110^{\circ}\right)$. The trigonid is wider than the talonid. The shape of the talonid is about the same as that of $\mathrm{P} / 4$, with the hypoconulid less posteriorly prominent.

$\mathrm{M} / 2$ is known only by its alveoli, the anterior one is still more inclined than in $\mathrm{M} / 1\left(\alpha=126^{\circ}\right)$. The posterior one does not enter deeply in the bone and is much oblique $\left(\alpha=151^{\circ}\right)$. The slope of the inter-alveoli zone is $135^{\circ}$, compared to the $110^{\circ}$ of the $\mathrm{M} / 1$.

There is not enough space for an $\mathrm{M} / 3$ in the dentary behind $\mathrm{M} / 2$ and before the large foramen mandibulare.

Geographic and stratigraphical distribution. Ravet (Quercy, France), Lower Oligocene (early Rupelian, MP 21). 


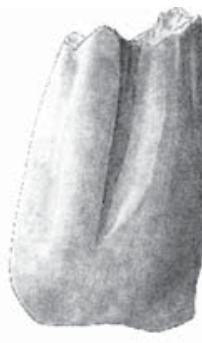

a

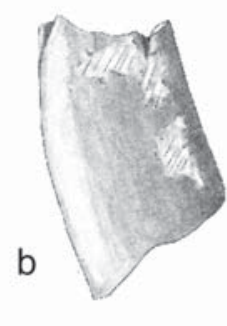

$1 \mathrm{~mm}$

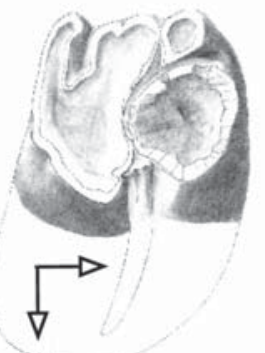

C

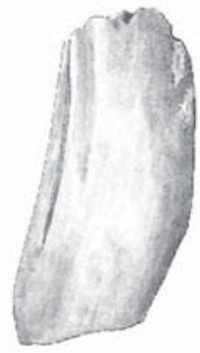

d
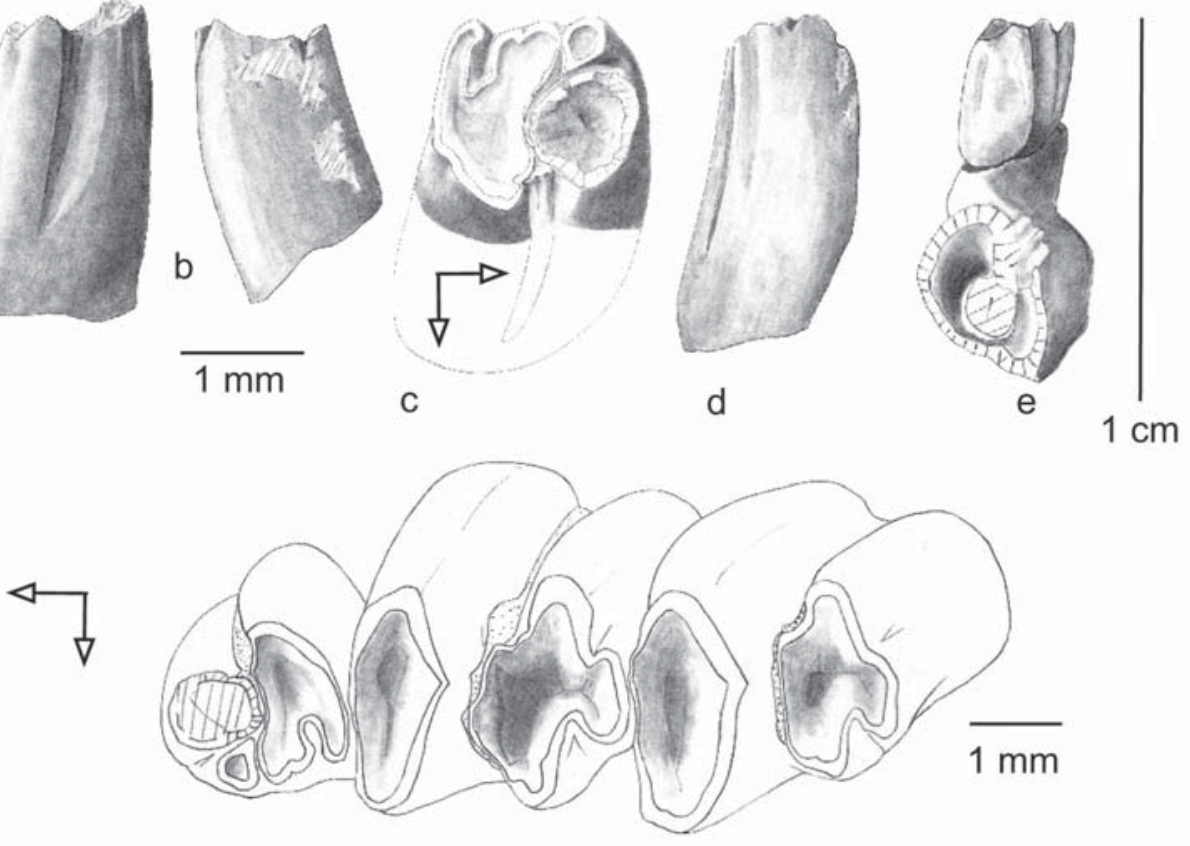

f

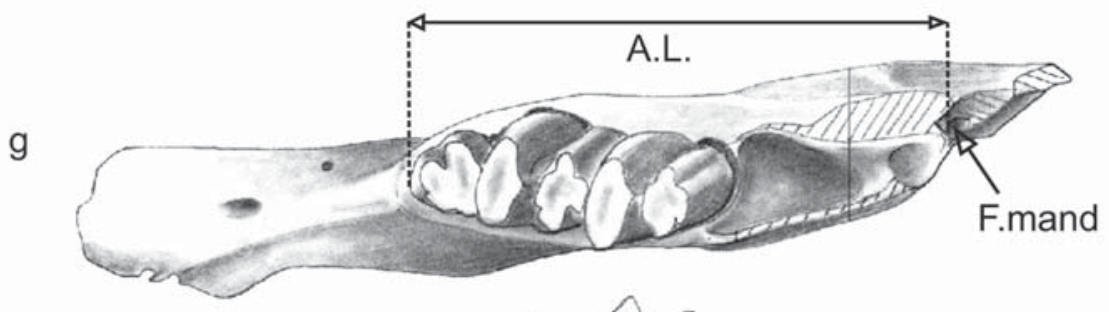

$\mathrm{h}$

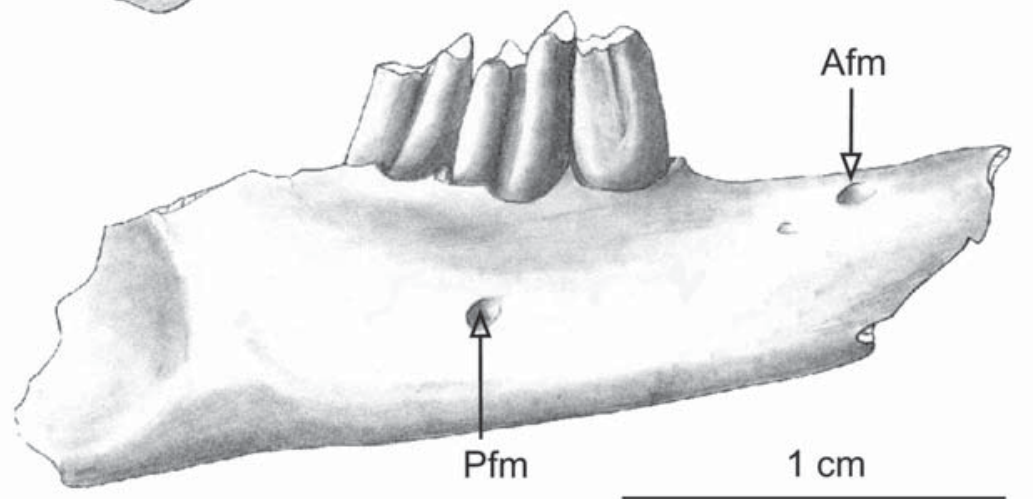

i

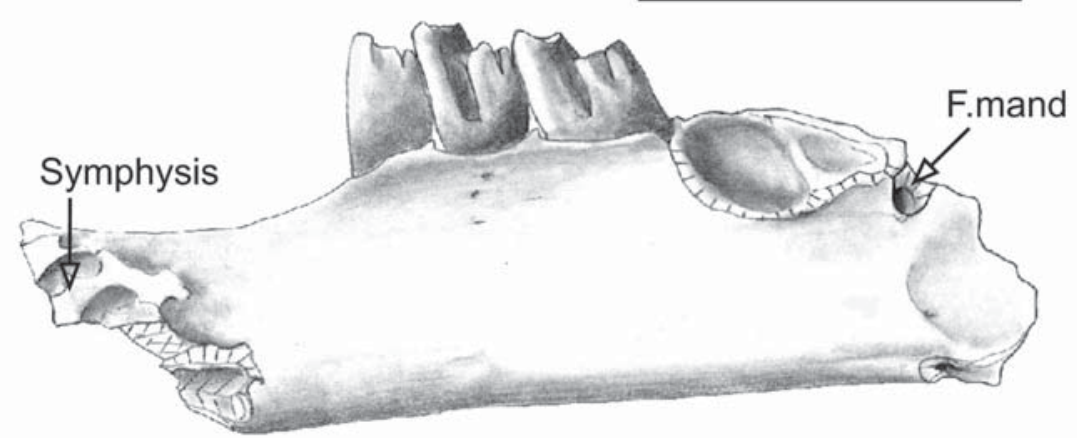

Figure 3. Drawings of Ephemerolagus nievae gen. nov. spec. nov., RAV546, from Ravet (Quercy MP21), body of the mandible, bearing $\mathrm{P} / 3, \mathrm{P} / 4, \mathrm{M} / 1$. a) Buccal view of $\mathrm{P} / 3$. b) Lingual view of $\mathrm{P} / 3$. c) Occlusal view of $\mathrm{P} / 3$. d) Front view of $\mathrm{P} / 3$. e) Front view of the mandible, showing the alveolus of the incisor and the mesial flank of $\mathrm{P} / 3$. f) Occlusal view of $\mathrm{P} / 3-\mathrm{P} / 4-$ $\mathrm{M} / 1$, enlarged. g) Dorsal view of the mandible. h) Buccal side of the mandible. i) Lingual side of the mandible. Arrows indicate mesial and lingual directions. F.mand = Foramen mandibulare; Afm = anterior foramen mentale; Pfm $=$ posterior foramen mentale; A.L. = alveolar length, $\mathrm{P} / 3$ to $\mathrm{M} / 2$ alveoli. 


\section{COMPARISONS AND DISCUSSION}

\subsection{Relationships with the contemporaneous European species "Shamolagus" franconicus (Heissig \& Schmidt-Kittler, 1975)}

If the pattern of the lower teeth of "Shamolagus" franconicus from Möhren 19 and 20 shows global similarity with that of Ethemerolagus nievae from Ravet, they differ in some respects: 1 ) The $\mathrm{P} / 3$ of " $S$ ". franconicus shows two well distinct and diverging roots (Heissig \& Schmidt-Kittler, 1975; Figs 1a-1b), whereas there are two closely attached and vertical roots in RAV546, 2) the occlusal surface shows that the metaconid is isolated from the protoconid, like in Ravet, but the mesoflexid and the metaflexid (of the same vertical height) are deeper than in Ravet, 3) the metaflexid extends more transversally on $E$. nievae, 4) the slope of the $\mathrm{M} / 2$ roots of "S." franconicus (Heissig \& Schmidt-Kittler, 1975; Figs 1-3) is clearly less steep than that of the $\mathrm{M} / 2$ alveoli of E. nievae, and 5) the $\mathrm{P} / 4$ (like $\mathrm{M} / 1$ ) of the latter shows two anterior roots; only one is visible on the $\mathrm{P} / 4$ of Möhren 20 (Heissig \& SchmidtKittler, 1976; Fig. 3).

Taking into account the above mentioned arguments, and the fact that the whole dental categories are not documented in both localities (lower teeth in Ravet, but neither DP/3 nor M/2; lower and upper teeth in Möhren 19 and 20 , including a $M / 3$, but no jaw), it seems accurate to distinguish the generic attribution of the early Oligocene lagomorph species of Southern Europe (Quercy), Ephemerolagus, from that from the Northern area (Bavaria), previously referred to Shamolagus. We cannot discuss fully the generic allocation of the latter. We can simply remark that it differs both from Titanomys and from Shamolagus in some respects: 1) from Titanomys in its double rooted $\mathrm{P} / 3$, and less asymmetrical triangular $\mathrm{P} 3 /$, and 2) from Shamolagus (at least from $S$. grangeri and $S$. medius) in a greater $\mathrm{P} / 4$, a much reduced $\mathrm{M} / 3$, and a lesser hypsodonty. It is probable that these species, from different areas and different ages, do not belong to the same genus, Shamolagus.

\subsection{Comparisons}

\subsubsection{Comparisons with late Eocene and early Oligocene semi-hypsodont species from Mongolia}

The ventral surface of the horizontal ramus of the dentary is not curved, while it is in Shamolagus grangeri (Meng et al., 2005; Figs 1-6), or Desmatolagus vetustus and D. gobiensis (Meng et al., 2005; Figs 1-7, 9), or irregularly inflated below $\mathrm{P} / 4-\mathrm{M} / 2$ in $D$. ardynense (Meng et al., 2005; Figs 1-8). As such, it better resembles Gobiolagus tolmachovi or G. andrewsi (Meng et al., 2005; Figs 1-1, 2 ). On the holotype of Desmatolagus (D. gobiensis), the anterior foramen mentale is much closer to the $\mathrm{P} / 3$ than in Ephemerolagus nievae. The posterior foramen mentale is below the trigonid of the $\mathrm{P} / 4$ in D. robustus (Matthew \& Granger, 1923) or in D. pusillus (Huang, 1987). It is a little posterior in the Ravet' specimen, like in Sinolagomys. But, in the latter, as well as in Desmatolagus, the depth of the jaw under $\mathrm{P} / 4$ to $\mathrm{M} / 1$ is clearly higher than in Ephemerolagus, the anterior foramen mentale being below the $\mathrm{P} / 3$, at mid-depth to the body, and the posterior one being close to its base, under the trigonid of $\mathrm{P} / 4$. The incisor alveolus ends below the anterior root of $\mathrm{P} / 3$, whereas it is far longer in Gobiolagus major (below the $\mathrm{M} / 2$ talonid), or in Desmatolagus vetustus (posteriorly to the trigonid of $\mathrm{M} / 2$ ).

The size of the teeth of Ephemerolagus is greater than that of the different samples of Desmatolagus gobiensis measured by Sych (1975) from the Oligocene localities from Inner Mongolia (groups I, II, III, IV). It is more similar in size to the D. robustus specimens of Sych (1975; p. 191-193) Desmatolagus is mainly characterized by reduction of $\mathrm{P} 2 /-\mathrm{P} / 3$ and $\mathrm{M} 2 /-\mathrm{M} / 3$ (Huang, 1987). Among these species, $D$. vetustus and $D$. ardynense are from late Eocene beds (Mongolia: Burke, 1941; Bohlin, 1942; Meng et al., 2005) and also from lower Oligocene beds, together with D. simplex, D. veletus and D. periaralicus (Mongolia and Khazakstan: Gureev, 1964; Erbajeva \& Däxner-Höeck, 2001; Erbajeva, 2007; Bendukidze et al., 2009; Erbajeva et al., 2011). $\mathrm{P} / 3$ is less reduced in Ephemerolagus than in these late Eocene/lower Oligocene lagomorphs, and $\mathrm{M} / 3$ is lacking. If the number of roots is variable in Gobiolagus (two or three) it is two on the unique specimen of $\mathrm{P} / 3$ from Ravet, and in "S." franconicus.

Ephemerolagus differs from Desmatolagus, Shamolagus and Gobiolagus in its more developed $\mathrm{P} / 4$. The orientation of the $\mathrm{P} / 3$ hypoflexid is less anteriorly open, like in Sinolagomys. $\mathrm{P} / 3$ differs also from that of $D$. vetustus in its rounded metaconid, isolated from the protoconid, but attached to the entoconid. In D. vetustus (V1475917), the talonid is more compressed, and does not show the metaflexid (= entoflexid) separating the entoconid from the posterolophid. Desmatolagus vetustus displays a medial connection between the posterior arm of the protoconid and the unique transverse lophid of the talonid. In Ephemerolagus, trigonid and talonid are separated by a complete mesoflexid, from labial to lingual sides of the tooth. But, this mesoflexid would rapidly disappear with wear, and be no longer distinguished on more worn specimen (between sections A and B in Figure 4b). In Gobiolagus, the trigonid of $\mathrm{P} / 3$ is wider and longer than the talonid. It is the contrary on Ephemerolagus, where the talonid is unreduced, like in Sinolagomys (Bendukidze et al., 2009; pl. 2, fig. 4). The $\mathrm{P} / 4$ of the specimen of $D$. vetustus from Ulan Gochu (Wang, 2007) is less developed 


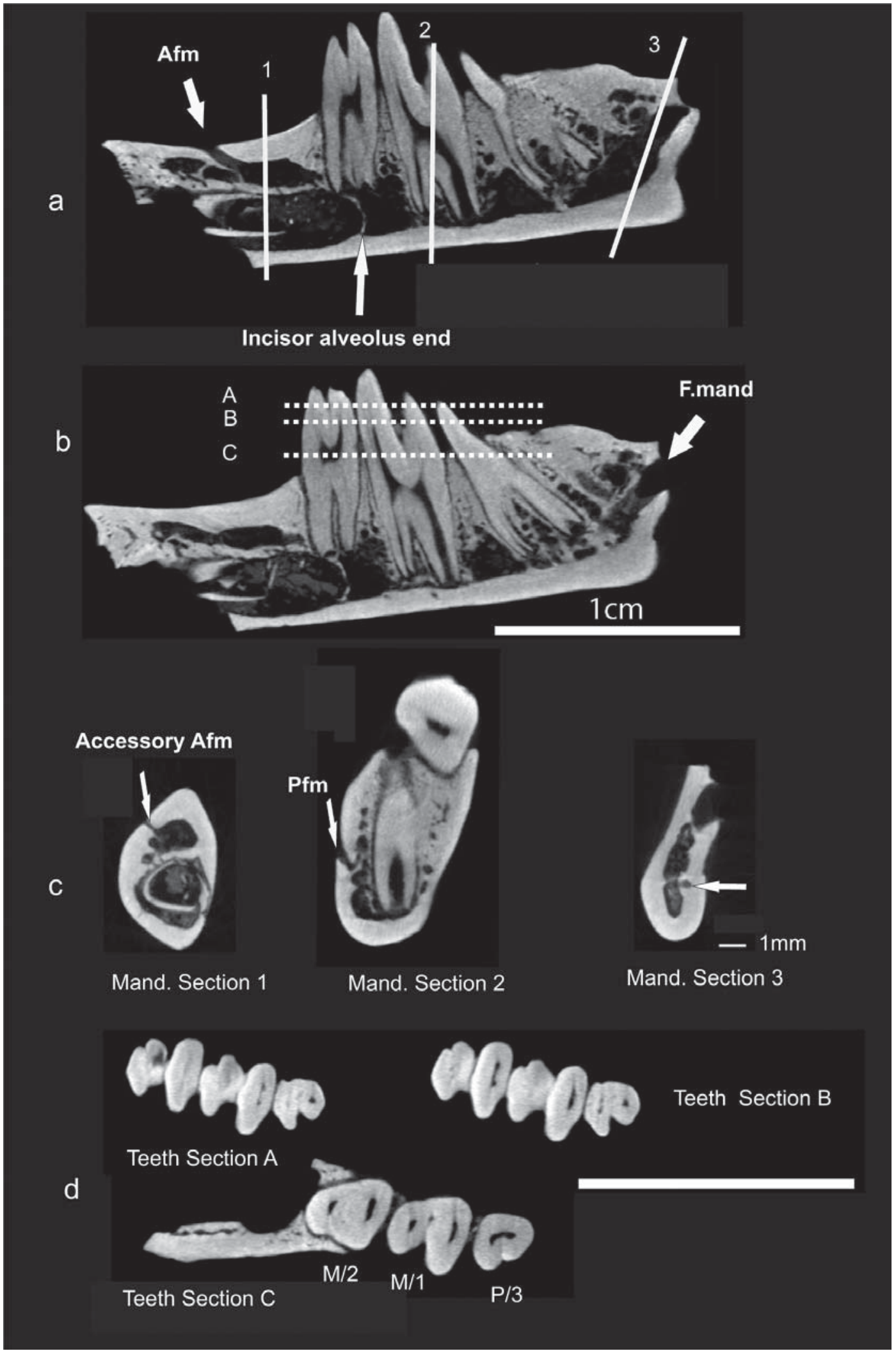

Figure 4. $\mu \mathrm{CT}$ sections of Ephemerolagus nievae gen. nov. spec. nov., RAV546, from Ravet (Quercy MP21). a) Sagittal section through the anterior mental foramen (Afm), the arrow indicates the end of the incisor alveolus. Lines 1, 2 and 3 correspond of the mandible sections 1, 2, 3. b) Sagittal section through the foramen mandibulare (F.mand). c) Mandibular front section 1 through the accessory anterior mental foramen; mandibular front section 2 through the posterior mental foramen; mandibular front section 3 through the tiny pterygoid foramen (arrow). d) Virtual sections of P/3 to M/1 (level of sections A, B, C, dotted lines in b). 
than that of Ephemerolagus, and notably the trigonid is smaller than the talonid, whereas it is the contrary on the lower Oligocene European specimens. $\mathrm{P} / 4$ is greater than $\mathrm{M} / 1$ in Ephemerolagus. This genus differs from Shamolagus and Strenulagus in the absence of $\mathrm{M} / 3$, and in $\mathrm{P} / 4$ as developed as M/1 (like in Sinolagomys and Desmatolagus). It differs from Strenulagus in the $\mathrm{P} / 4$ trigonid greater than the talonid.

\subsubsection{Comparisons with late Eocene and early Oligocene North American Paleolagidae}

Ephemerolagus differs from Mytonolagus Walker, Palaeolagus Leidy, Chadrolagus Gawne and Megalagus Walker (e.g., Burke, 1941; Dawson, 1958, 1970; Gawne, 1978) and other North American Paleolagidae especially in its less hypsodont cheek teeth, its strong molarization of $\mathrm{P} / 4$, greater than $\mathrm{M} / 1$, and the lack of $\mathrm{M} / 3$. Compared to the short incisor of Ephemerolagus (below $\mathrm{P} / 3$ trigonid), it terminates far posterior in Mytonolagus in line below the anterior of M/2 (Dawson, 1970), less in Palaeolagus (between $\mathrm{P} / 4$ and $\mathrm{M} / 1$ ) and it is slightly longer in Chadrolagus (between $\mathrm{P} / 3$ talonid and $\mathrm{P} / 4$ ).

\subsubsection{Comparisons with late Oligocene genera Amphilagus Pomel and Titanomys H. v. Meyer}

"Shamolagus" franconicus was first referred by Heissig \& Schmidt-Kittler (1975) to the genus Titanomys because it could represent an evolutionary grade precursor to that of Titanomys. Indeed, a trend could have been detected between this species and Amphilagus, Titanomys and Piezodus, as the reduction of $\mathrm{M} / 3$ and the high molarization of $\mathrm{P} / 4$, at least equal in size with $\mathrm{M} / 1$. A similar trigonid-talonid position is observed in early ("Shamolagus" franconicus and Ephemerolagus nievae) and late (Amphilagus antiquus) Oligocene European lagomorph genera, notably on $\mathrm{P} / 4$. There is a kind of labial shift of the talonid lingual border, whereas there is a lingual shift of the talonid labial border in Asian species, combined with a talonid clearly narrower than the trigonid (i.e., Meng et al., 2005; figs 2-3, 6-10; Bendukidze et al., 2009; figs $2,4,10)$. The $\mathrm{P} / 3$ of Amphilagus antiquus is variable but lacks a high anteroconid reaching the occlusal surface. When present, it is weak and low (Tobien, 1970; fig. 3). It increases in height in Miocene species of Amphilagus or in Piezodus, but not in Titanomys (Tobien, 1963, 1974). The mesoflexid is mesio-distally wider on the $\mathrm{P} / 3$ of Titanomys than in Ephemerolagus, and also than in Amphilagus and Piezodus. One can imagine that the weakly worn $\mathrm{P} / 3$ from Ravet, after a strong wear, will show a relatively simple pattern, with only a short hypoflexid and a lingual continuity between trigonid and talonid, as seen on Scan virtual sections (Fig. 4).
Ephemerolagus is greater and less hypsodont than Amphilagus antiquus. The high hypsodonty of the latter involve a deeper horizontal ramus of the dentary as a result.

A striking specificity of $E$. nievae is the shortness of the lower incisor. No mention of such a brief incisor has been found in the published papers on early lagomorphs. The shorter is reported in North American Chadrolagus (between $\mathrm{P} / 3$ talonid and $\mathrm{P} / 4$ ). Even in a juvenil specimen of Amphilagus, such as A. wutktkei (Mörs \& Kalthoff, 2010), the DI/2 ends at least below the anterior root of $\mathrm{M} / 1$.

\subsubsection{Length of incisor and hypsodonty of lower jugal teeth: Mastication pattern}

Bohlin (1942; p. 63-64) discussed the observations made by Wood (1940) concerning the relation between the position of the lower incisor and that of the cheek teeth. Wood noted that the incisor was long in Palaeolagus and Mytonolagus, growing below the lingual part of the premolars, then producing a knob on the lingual side of the mandible, situated below $M / 1$ or between $M / 1$ and $M / 2$. For him, this early buccal shift of cheek teeth would be a result of the long incisor previously appeared, as in Eurymylus. Wood supposed that, with increasing hypsodonty of cheek teeth, this lingual position was not sufficient to have space enough to the high crowns, and a continual shortening of the incisors did occur. Bohlin disagreed, thinking that "the conflict between the growth of the tooth prisms and the length of the incisors was settled long before the retraction of the incisor set in" (Bohlin, 1942; p. 64).

One can add that the shortening of the incisor occurs in parallel, and at different epochs, among different lagomorph lineages, and at different degrees (e.g., Bohlin, 1942; fig. 19). It occurred independently of the lingual shift of the incisor, which being soon established within the glires. The shortening is the rule in modern leporids and, at a lesser extent, in modern ochotonids. These modern forms are all completely hypsodont. Among the early Oligocene lagomorphs, Ephemerolagus nievae is the most advanced genus for this character, despite the fact the cheek teeth are not completely hypsodont. Is this fact related with a peculiar diet? It could be dubious, because the dental morphologies of lagomorphs are not so diverse. For example, the Mexican Romerolagus and the African Pronolagus are very similar in dental functional pattern, while their food spectra are quite distinct (von Koenigswald et al., 2010). Thus, we have followed the methods and observations of these authors on the mastication patterns of lagomorphs, in order to determine that of Ephemerolagus. Like in other derived stem lagomorphs as Palaeolagus, or primitive ochotonids Amphilagus or Titanomys, Ephemerolagus nievae displays 
a unique $\mathrm{V}$-shaped primary shearing blade, broken down into two phases (PSB, Ia and Ib) on $\mathrm{P} / 4$ and $\mathrm{M} / 1-2$. The traces of orthal movements can be found in the uplift of the mesial border of the talonid of $\mathrm{P} / 4$; its thin enamel cover is stuck against the distal border of the trigonid, and the attached dentine is vertical whereas that of the main part of the talonid basin is concave in the horizontal plane. This wear facet is in continuity with the posterior slope of the enamel surface of the PSB (Fig. 5). It is the result of the first phase of power stroke (phase Ia, according to von Koenigswald et al., 2010). The metaconid is slightly higher than the protoconid, and the entoconid than the hypoconid (mainly seen on $\mathrm{P} / 4$, less worn). Then, the deepening of the talonid is achieved by the grinding effect of the lingual move of the metaconule part (crescent) of the opposite upper teeth (phase Ib of power stroke). The upper teeth of E. nievae are unknown, and we cannot directly check the occlusal pattern. But we can hypothesize that the precingulum would have represented the primary shearing blade of the upper cheek teeth.

It could be the case for "Shamolagus" franconicus, in which the mesial enamel layer (the precingulum) is the only thick enamel layer, as seen on weakly worn P4/, M1/ and M2/. It would occlude with the lower PSB. Then, the crescent (displaying horizontal facet) would move lingually within the talonid basin (see Heissig \& Schmidt-Kittler, 1976; fig. 11a); wear would act horizontally. This kind of masticatory pattern is a primitive one, and cannot explain the lower incisor shortness for Ephemerolagus.

\section{CONCLUSIONS}

The main objective of this paper was to describe a new genus and species of an early Oligocene European lagomorph, Ephemerolagus nievae, on the basis of new material from Ravet (Quercy, MP21, $33 \mathrm{Ma}$ ). Phylogenetic relationships could be supposed between this taxon and the late Oligocene European lagomorphs, due to some morphological general trends. They share the general shape of the $\mathrm{P} / 3$ and the strong development of $\mathrm{P} / 4$ with an enlarged trigonid, allied with the loss of $\mathrm{M} / 3$ (as in Piezodus or, sometimes later, in Titanomys). But, they diverge mainly in the length of their lower incisor and in having weaker hypsodonty. If the different degree of hypsodonty could be due to the temporal gap between them, and does not preclude phylogenetical relationships, the incisor shortness represents a different evolutionary trend for Ephemeromys, and its functional meaning is problematic. The above cited characters are not observed

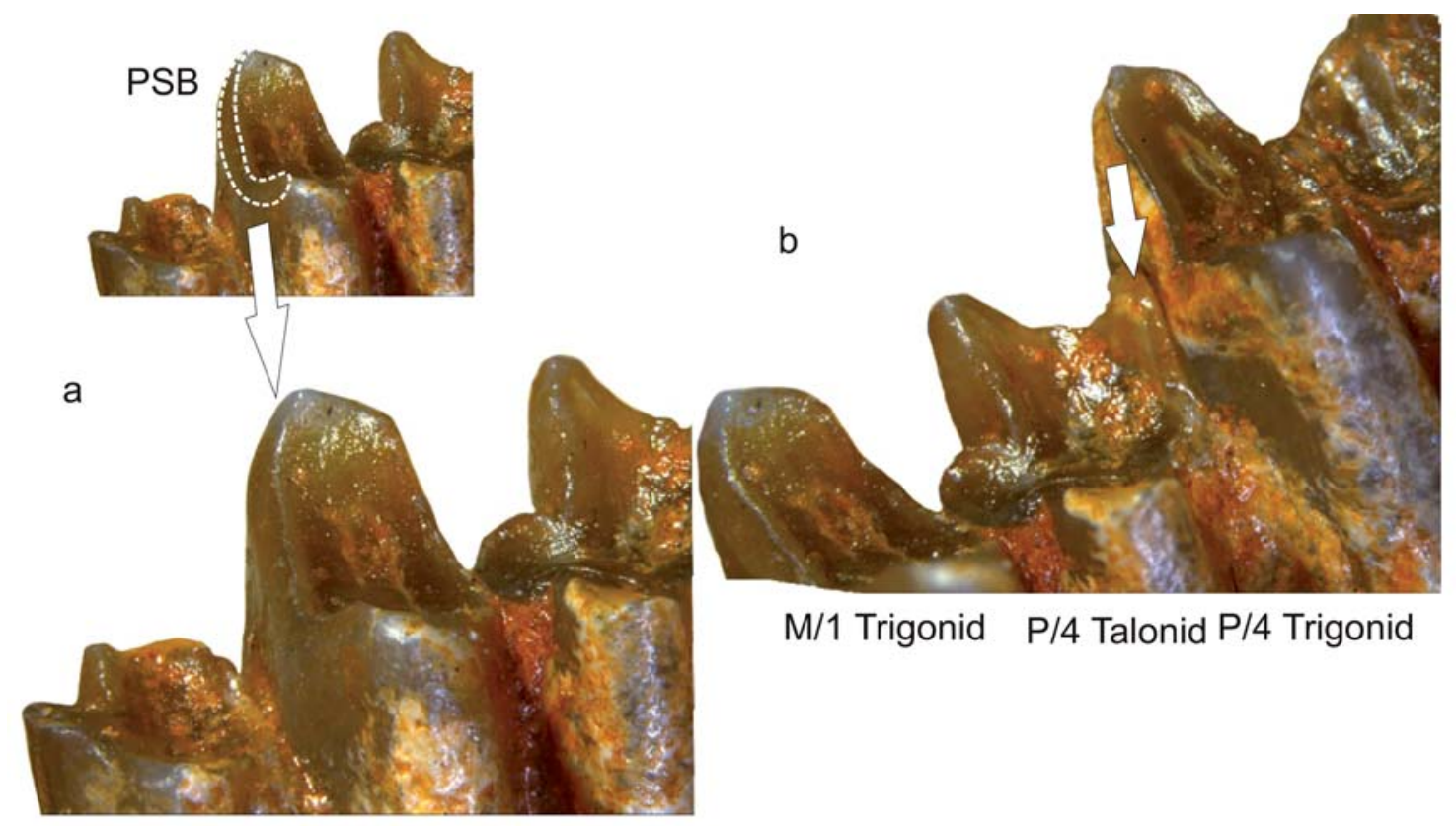

M/1 Talonid M/1 Trigonid P/4 Talonid

Figure 5. Ephemerolagus nievae gen. nov., spec. nov., RAV546, Ravet (Quercy, MP21). a) Primary shearing blade (PSB) on the enamel surface of the $\mathrm{M} / 1$ talonid postcingulum (dotted line in the small picture above, and white arrow, on the enlarged picture, below). b) The orthal facet PSB is less visible on the $\mathrm{P} / 4$ trigonid due to the weathered enamel, but the uplift of the anterior cingulum of the $\mathrm{P} / 4$ talonid against it is clear, as a component of this facet (white arrow). 
in the late Eocene and early Oligocene Asian and North American genera. The similarities observed with those groups are mainly plesiomorphies, like the unilateral hypsodonty; the reduction of $\mathrm{M} / 3$ in Asian genera is never as extensive as in the European genera. Thus, the early relationships of Ephemerolagus remain uncertain, as well as its familial allocation.

The immigration of lagomorphs in Western Europe occurred almost simultaneously, in three post-GrandeCoupure localities, whereas about 18 sub-contemporaneous sites have yielded rodents (Biochro'M, 1997), and Ephemerolagus is found only in one. They differentiate rapidly, as they display a few derived characters and some of them different in Germany and Southern France. In these areas they have to compete with semi-hypsodont rodents, showing similar locomotion, like issiodoromyine theridomyids (e.g., Vianey-Liaud, 1976, 1979), and also with the small species of cainotheriid artiodactyls (Blondel, 2005). The theridomyids, and among them the Theridomyinae and Issiodoromyinae, remained the most abundant rodents during the relatively cool and arid early Oligocene environments (Vianey-Liaud et al., 1995; VianeyLiaud, 1998), while the lagomorphs have disappeared from the European fossil record soon after their appearance (after level MP21). Theridomyids have developed highly specialized cheek teeth (increasing hypsodonty, lophodonty or simplification of occlusal pattern) as soon as the early Oligocene, whereas Ephemerolagus cheek teeth are not so much specialized. The theridomyids decrease in diversity together with the increase of temperature and humidity during the late Oligocene (De Man \& Van Simeyes, 2004). It became the time of a new immigration for lagomorphs (since MP28 level, $24.7 \mathrm{Ma}$, Mertz et al., 2007), in completely different climatic and faunistic conditions than those known by Ephemerolagus at the beginning of the Oligocene in Western Europe.

\section{ACKNOWLEDGEMENTS}

This research was supported by the "Institut des Sciences de l'Evolution", UMR 5554 Université Montpellier 2-CNRS. L. Marivaux granted access to the multifocus stereomicroscopic camera funded by the ANR-ERC Palasiafrica Program (ANR-08-JCJC-017), took the picture illustrated in Fig. 5. We benefited of the X-ray microtomograph of the Montpellier RIO imaging platform. Many thanks to Gertrud Rössner, Kurt Heissig, and Jerôme Prieto who made and sent the photographs, for giving us the ability to have a view on the material of lagomorph from Möhren 19 and Möhren 20. We are indebted to the two reviewers whose comments have been used to improve this paper. Publication $n^{\circ}$ ISE-M 2012-285.

\section{REFERENCES}

Angelone, C. 2007. Messinian Prolagus (Ochotonidae, Lagomorpha) of Italy. Géobios, 40, 407-421.

Averianov, A.O. 1998. Homology of the cusps in the molars of the Lagomorpha (Mammalia) and certain general problems of homology in the morphological structures. Paleontological Journal, 1, 76-81.

Averianov, A.O. \& Lopatin, A.V. 2005. Eocene lagomorphs (Mammalia) of Asia: 1. Aktashmys (Strenulagidae fam. nov.). Paleontological Journal, 39, 308-317.

Bendukidze, O.G., de Bruijn, H. \& van den Hoek Ostende, L.W. 2009. A revision of Late Oligocene associations of small mammals from the Aral Formation (Kazakhstan) in the National Museum of Georgia, Tbilissi. Palaeodiversity, 2, 343-377.

BiochroM'97. 1997. Oligocene: Syntheses and Correlation tables, In: Colloque BIOCHROM, Montpellier, Avril 1997 (eds. Aguilar, J.P., Legendre, S. \& Michaux, J.). Mémoires et Travaux de l'Ecole Pratique des Hautes Etudes, Montpellier, 21, 769-805.

Blondel, C. 2005. New data on the Cainotheriidae (Mammalia, Artiodactyla) from the early Oligocene of south-western France. Zoological Journal of the Linnean Society, 144, 145-166.

Bohlin, B. 1942. The fossil mammals from the Tertiary deposits of Taben-Buluk, western Kansu. Part 1. Insectivora and Lagomorpha. Paleontologica Sinica, ser C, 8, 1.113.

Burke, J.J. 1941. New fossil Leporidae from Mongolia. American Museum Novitates, 1117, 1-23.

Dawson, M.R. 1958. Late Tertiary Leporidae of North America. University of Kansas, Paleontological Contributions. Vertebrata, 6, 1-75.

Dawson, M.R. 1967. Lagomorph History and the Stratigraphic Record. Essays in Paleontology and Stratigraphy Raymond C. Moore Commemorative Volume. University of Kansas Department of Geology Special Publication, 2, 287-316.

Dawson, M.R., 1970. Paleontology and geology of the Badwater Creek area, central Wyoming, 6. The leporid Mytonolagus (Mammalia, Lagomorpha). Annals of Carnegie Museum, 41, 215-230.

De Man, E. \& Van Simayes, S. 2004. Late Oligocene Warming Event in the southern Noth Sea Basin: benthic foraminifera as paleotemperature proxies. Netherlands Journal of Geosciences / Geologie en Mijnbouw, 83, 227-239.

Erbajeva, M.A. 2007. Lagomorpha (Mammalia): preliminary results. In: Oligocene-Miocene Vertebrates from the Valley of Lakes (Central Mongolia): Morphology, Phylogenetic and Stratigraphic Implications (ed. Daxner-Höck G.). Part 5, Annalen des Naturhistorisches Museum in Wien, 108A, 165-171.

Erbajeva, M.A. \& Däxner-Höeck, G. 2001. Paleogene and Neogene lagomorphs from the Valley of lakes, central Mongolia. Lynx, Praha, n.s. 32, 55-65. 
Erbajeva, M.A., Mead, J.I., Aleexeeva, N.V., Angelone, C. \& Swift, S. 2011. Taxonomic diversity of Late Cenozoic Asian and North American ochotonids (an overview). Palaeontologia Electronica, 14, 42a, 9 p.

Gawne, C.E. 1978. Leporids (Lagomorpha, Mammalia) from the Chadronian (Oligocene) deposits of Flagstaff Rim Wyoming. Journal of Paleontology, 52, 1103-1118.

Gureev, A.A. 1964. Fauna of the USSR, Mammals, Lagomorphs (Lagomorpha, Mammalia), Moscow (Nauka) (in Russian), 1-276.

Heissig, K. \& Schmidt-Kittler, N. 1975. Eine primitiver Lagomorphe aus dem Mitteloligozän Süddeustchlands. Mitteilungen der Bayerischen Staatssammlung für Paläontologie und Historische Geologie, 15, 57-62.

Heissig, K. \& Schmidt-Kittler, N. 1976. Neue LagomorphenFunde aus dem Mitteloligozän. Mitteilungen der Bayerischen Staatssammlung für Paläontologie und Historische Geologie, 16, 83-93.

Huang, H. 1987. Fossil ochotonids from the middle Oligocene of Ulantatal, Nei Mongol, Vertebrata PalAsiatica, 22, 163-178 (in Chinese, English summary).

Kraatz, B.P., Meng, J., Weksler, M., \& Li, C.K. 2010. Evolutionary patterns in the dentition of Duplicidentata (mammalia) and a novel trend in the molarization of premolars. PlosOne, 5, 1-15, e12838.

Li, C.K. 1965. Eocene Leporids of North China. Vertebrata PalAsiatica, 9, 23-36.

Lopatin, A.V. \& Averianov, A.O. 2006. Eocene Lagomorphs (Mammalia) of Asia: 2. Strenulagus and Gobiolagus (Strenulagidae). Paleontological Journal, 40, 198-206.

López-Martínez, N. 1974. Evolution de la Lignée PiezodusProlagus (Lagomorpha, Ochotonidae) dans le Cénozô̂que d'Europe Sud-Occidentale. Thèse, Montpellier Université des Sciences et Techniques du Languedoc.

López-Martínez, N. 2008. The lagomorph fossil record and the origin of the European rabbit. In: Lagomorph Biology, Evolution, Ecology, and Conservation (eds. Alves, P.C., Ferrand, N. \& Hackländer, K.). Springer-Verlag, Berlin Heidelberg, 27-46.

López-Martínez, N. \& Thaler, L. 1975. Sur le plus ancien lagomorphe européen et la «Grande Coupure» oligocène de Stehlin. Palaeovertebrata, 6, 243-251.

Martin, T. 2004. Evolution of incisor enamel microstructure in Lagomorpha. Journal of Vertebrate Paleontology, 24, 411-426.

Matthew, W.D. \& Granger, W. 1923. Nine new rodents from the Oligocene of Mongolia. American Museum Novitates, 102, 1-10.

Meng, J. \& Hu, Y. 2004. Lagomorpha, Mammalia, from the Yihesubu Late of Nei Mongol (Inner Mongolia). Vertebrata PalAsiatica, 42, 261-275.

Meng, J., Hu, Y. \& Li, Ch. 2005. Gobiolagus (Lagomorpha, Mammalia) from Eocene Ula Usu, Inner Mongolia, and comments on Eocene lagomorphs of Asia. Paleontologica Electronica, 8, 7A, 23 p.

Mertz, D.F., Renne, P.R., Wuttke, M. \& Mödden, C. 2007. A numerically calibrated reference level (MP28) for the terrestrial mammal-based biozonation of the European
Upper Oligocene. International Journal of Earth Sciences, 96, 353-361.

Mörs, T. \& Kalthoff, D. 2010. A new species of Amphilagus (Mammalia: Lagomorpha) from the Late Oligocene lake deposits of Enspel (Westerwald, Germany). Paleobiology Paleoenvironment, 90, 83-98.

Pomel, A. 1853. Catalogue Méthodique et Descriptif des Vertébrés Fossiles Découverts dans le Bassin Hydrographique Supérieur de la Loire et Surtout dans la Vallée de son Affluent Principal, l'Allier. Baillère, J.B., Paris.

Rose, K.D., Burke DeLeon, V., Missiaen, P., Rana, R.S., Sahni, A., Singh, L. \& Smith, T. 2008. Early Eocene lagomorph (Mammalia) from Western India and the early diversification of Lagomorpha. Proceedings of the Royal Society B, 275, 1203-1208.

Stehlin, H.G. 1909. Remarques sur les faunules de mammifères des couches éocènes et oligocènes du bassin de Paris. Bulletin de la Société Géologique de France, 4, 488-520.

Sych, L. 1975. Lagomorpha from Oligocene of Mongolia. Paleontologica Polonica, 3, 183-200.

Tobien, H. 1963. Zur gebiß-entwicklung tertiärer Lagomorphen (Mamm.) Europas. Notizblatt des hessischen Landesamtes für Bodenforschung zu Wiesbaden, 91, 15-35.

Tobien, H. 1970. Lagomorph aim Unter-Miozän des Mainzer Beckens und die altesstellung der Fundschichten. Abhandlungen des Hessischen Landesamtes für Bodenforschung, 56 (Falke-Festschrift), 13-36.

Tobien, H. 1974. Zur gebißstruktur, systematik und evolution der genera Amphilagus und Titanomys (Lagomorpha, Mammalia) aus einigen Vorkommen im jüngeren Tertiär Mittel und Westeuropas. Mainzner geowissenschaften Mitteleitlungen, 3, 95-214.

Tobien, H. 1978. Brachyodonty and hypsodonty in some Paleogene Eurasian lagomorphs. Mainzner geowissenschaften Mitteleitlungen, 6, 161-175.

Tobien, H. 1986. Deciduous teeth of Desmatolagus (Lagomorpha, Mammalia) from the Mongolian Oligocene and of related European Genera. Quartärpaläontolgie, 6, 223-229.

Vianey-Liaud, M. 1976. Les Issiodoromyinae (Rodentia, Theridomyidae) de l'Eocène supérieur à l'Oligocène inférieur en Europe Occidentale. Palaeovertebrata, 7, 1-115.

Vianey-Liaud, M., 1979. Evolution des rongeurs à l'Oligocène en Europe Occidentale. Palaeontographica, A, 166, 136236.

Vianey-Liaud, M. 1998. La radiation des Theridomyinae (Rodentia) à l'Oligocène inférieur: modalités et implications biochronologiques. Geologica et Paleontologica, 32, 253285.

Vianey-Liaud, M., Comte, B. \& Lévêque, F. 1995. Le Garouillas et les sites contemporains (Oligocène MP25) des phosphorites du Quercy (Lot, Tarn et Garonne, France) et leurs faunes de vertébrés: Rongeurs. Palaeontographica, A, 236, 257-326.

Viret, J. 1929. Les faunes de mammifères de l'Oligocène supérieur de la Limagne Bourbonnaise. Annales de l'Université de Lyon, 1, 1-47. 
von Koenigswald, W., Anders, U., Engels, S., Schultz, J. \& Ruf, I. 2010. Tooth morphology in fossil and extant Lagomorpha (Mammalia) reflects different mastication patterns. Journal of Mammalian Evolution, 17, 275-299. von Meyer, H., 1843. Sümmarische Uerbersicht der fossilen Wirbeltiere des Mainzer tertiär-Beckens, mit besonderer Rücksicht auf Weisenau. Neues Jahrbuch für Mineralogie, Geologie und Paläontologie, 1843, 379-410.

Wang B.-Y. 2007. Late Eocene Lagomorphs from Nei Mongol, China. Vertebrata PalAsiatica, 1, 43-58.
Wible, J.R. 2007. On the cranial osteology of the Lagomorpha. In: Mammalian Paleontology on a Global Stage: Papers in Honor of Mary R. Dawson (eds. Beard, C.K. \& Luo, Z.X). Bulletin of Carnegie Museum of Natural History, 39, 213-234.

Wood A.E. 1940.The Mammalian fauna of the White River Oligocene. Part III Lagomorpha. Transactions of the American Philosophical Society, 28, 271-362. 